\title{
Influence of Lactobacillus buchneri as silage additive and forage:concentrate ratio on the growth performance, fatty acid profile in longissimus muscle, and meat quality of beef cattle
}

\author{
C.H.S. Rabelo, F.C. Basso, T.A. McAllister, J.F. Lage, G.S. Gonçalves, E.C. Lara, A.A. Oliveira, \\ T.T. Berchielli, and R.A. Reis
}

\begin{abstract}
Our objective was to investigate Lactobacillus buchneri as a silage additive and the forage:concentrate (F:C) ratio on growth performance and meat quality of finishing beef cattle. The trial was a 2 (corn silage untreated or inoculated with $L$. buchneri) $\times 2$ (two F:C ratios, 60:40 or 40:60) factorial. Bulls fed a 40:60 F:C diet containing inoculated silage had greater dry matter $(D M)$ intake $(P<0.01)$ and average daily gain $(P=0.029)$ compared with other treatments. DM $(P=0.02)$ and neutral detergent digestibility $(P<0.01)$ were depressed by inoculation of corn silage with L. buchneri. Thiobarbituric acid concentration in meat increased $(P<0.01)$ by $15 \%$ in bulls fed the $60: 40$ $\mathrm{F}: \mathrm{C}$ diet compared with the 40:60 F:C diet. Inoculation of silage increased $(P=0.02)$ the ratio of unsaturated fatty acids to saturated fatty acids. Compared with the 60:40 F:C diet, the concentrations of polyunsaturated fatty acids $(P=0.03)$ and omega-6 fatty acids $(P=0.02)$ increased in longissimus muscle by $23 \%$ and $26 \%$, respectively, in bulls fed the 40:60 F:C diet. Inoculation of corn silage with L. buchneri inconsistently improved the growth performance and meat traits of finishing bulls consuming diets differing in F:C.
\end{abstract}

Key words: corn silage, digestibility, fatty acid profile, Lactobacillus buchneri, ruminal fermentation.

Résumé : Notre objectif était d'étudier Lactobacillus buchneri comme supplément à l'ensilage et le rapport fourrage: concentré $(\mathrm{F}: \mathrm{C})$ sur la performance de croissance et la qualité de viande des bovins de boucherie en finition. L'étude a été effectuée au moyen d'un factoriel 2 (ensilage de maïs non traité ou inoculé à L. buchneri) $\times 2$ (deux rapports F:C, 60:40 ou 40:60). Les taureaux ayant reçu la diète $\mathrm{F}: \mathrm{C}$ 40:60 avec ensilage inoculé montraient une prise alimentaire de matières sèches $(\mathrm{DM}-$ - dry matter ») plus élevée $(P<0,01)$ et un gain moyen quotidien plus élevé $(P=0,029)$ par rapport aux autres traitements. Les $\mathrm{DM}(P=0,02)$ et la digestibilité au détergent neutre $(P<0,01)$ étaient plus faibles avec l'ensilage de maïs inoculé au L. buchneri. La concentration d'acide thiobarbiturique dans la viande a augmenté $(P<0,01)$ de $15 \%$ chez les taureaux ayant reçu la diète à $\mathrm{F}: \mathrm{C}$ 60:40 par rapport à la diète à $\mathrm{F}: \mathrm{C}$ 40:60. L'inoculation de l'ensilage a augmenté $(P=0,02)$ le rapport d'acides gras insaturés:acides gras saturés. Par rapport à la diète à $\mathrm{F}: \mathrm{C}$ 60:40, les concentrations d'acides gras polyinsaturés $(P=0,03)$ et d'acides gras oméga- $6(P=0,02)$ ont augmenté dans le muscle longissimus par $23 \%$ et $26 \%$, respectivement, chez les taureaux ayant reçu la diète à F:C 40:60. L'inoculation de l'ensilage de maïs à la L. buchneri a amélioré la performance de croissance et les caractéristiques de la viande de façon inconsistante chez les taureaux en finition nourris de diètes qui diffèrent en F:C. [Traduit par la Rédaction]

Mots-clés : ensilage de maïs, digestibilité, profil d'acide gras, Lactobacillus buchneri, fermentation dans le rumen.

Received 27 October 2015. Accepted 25 April 2016.

C.H.S. Rabelo, F.C. Basso, J.F. Lage, G.S. Gonçalves, E.C. Lara, A.A. Oliveira, T.T. Berchielli, and R.A. Reis. Department of Animal Sciences, São Paulo State University, Jaboticabal, SP 14884-900, Brazil.

T.A. McAllister. Agriculture and Agri-Food Canada Research Centre, Lethbridge, AB T1J 4B1, Canada.

Corresponding author: C.H.S. Rabelo (email: carlos.zoo@hotmail.com).

Abbreviations: ADF, acid detergent fiber; ADG, average daily gain; ADIN, acid detergent insoluble nitrogen; BW, body weight; CL, cooking losses; CLA, conjugated linoleic acids; CP, crude protein; DM, dry matter; DMI, dry matter intake; EE, ether extract; F:C, forage:concentrate ratio; FFA, free fatty acids; FID, flame ionization detector; HDL, high-density lipoprotein; iNDF, indigestible neutral detergent fiber; ISHC, inoculated silage and high amount of concentrate; ISLC, inoculated silage and low amount of concentrate; LAB, lactic-acid bacteria; LDL, low-density lipoprotein; LMA, longissimus muscle area; MUFA, monounsaturated fatty acids; NDF, neutral detergent fiber; NFC, nonfiber carbohydrate; PDA, potato dextrose agar; PUFA, polyunsaturated fatty acid; RFT, rib fat thickness; SFA, saturated fatty acid; TBA, thiobarbituric acid; UFA, unsaturated fatty acid; USHC, untreated silage and high amount of concentrate; USLC, untreated silage and low amount of concentrate; VFA, volatile fatty acid; WBSF, Warner-Bratzler shear force.

(c) Her Majesty the Queen in right of Canada 2016. Permission for reuse (free in most cases) can be obtained from RightsLink. 


\section{Introduction}

Lactobacillus buchneri has been successfully used as a silage inoculant to enhance the aerobic stability of silages via the anaerobic conversion of lactic acid into acetic acid and 1,2-propanediol (Oude Elferink et al. 2001; Kleinschmit and Kung 2006). The ability of L. buchneri to produce antifungal by-products (e.g., acetic acid) may be particularly beneficial in preventing the spoilage of silages produced under tropical conditions (Ashbell et al. 2002). Moreover, improvements in dry matter intake (DMI), feed efficiency, and weight gain of animals fed silages inoculated with $L$. buchneri have been reported (Ranjit et al. 2002; Basso et al. 2014). Enhanced growth performance likely arises from improvements in silage quality, along with possible probiotic effects from lactic-acid bacteria (LAB) in the silage (Weinberg et al. 2003; Mohammed et al. 2012; Han et al. 2014). Few studies have investigated the effect of L. buchneri as a singular inoculant, although a recent study found that it enhanced the microbial $\mathrm{N}$ supply in lambs fed corn silage (Basso et al. 2014).

Additionally, in recent years, there has been a surge in consumer interest toward how livestock diet can be favorably altered to improve meat quality of beef cattle so as to promote health and prevent disease in humans (Scollan et al. 2006). One way to positively change meat quality is to increase the polyunsaturated fatty acid (PUFA) content of the diet or to alter the biohydrogenation process in the rumen (Jenkins 1993; Ander et al. 2003). In this regard, L. buchneri is able to produce antimicrobial substances such as buchnericin (Yildirim 2001), and it has been proposed that it may alter microbial populations in silage and possibly in the rumen (Weinberg et al. 2003). Furthermore, lipids reaching the duodenum do include those that are of microbial origin (Jenkins 1993). Thus, the production of antimicrobial substances by L. buchneri could alter biohydrogenation processes in silage and possibly the rumen, with this impact being particularly directed toward Gram-positive bacteria (Klaenhammer 1993).

Moreover, different forage:concentrate $(\mathrm{F}: \mathrm{C})$ ratios can impact meat quality and the fatty acid profile of meat (Mandell et al. 1998; Ryan et al. 2007; Warren et al. 2008). Compared with high-grain diets, a high-grass diet can increase the PUFA:saturated fatty acid (SFA) ratio and conjugated linoleic acids (CLAs) in intramuscular fat of beef cattle (French et al. 2000; Nuernberg et al. 2005). Varying the F:C ratio would influence the level of L. buchneri administered to the animal through inoculated silage. Although there are no data on the impact of different levels of L. buchneri administered on the growth performance and fatty acid composition of beef cattle, changes in fermentation (i.e., high production of acetic acid and aerobic stability) of silage have been reported (Kleinschmit and Kung 2006). Thus, we hypothesized that the use of different F:C ratios may alter the level of L. buchneri administered and change the fatty acid composition and performance of beef cattle.

Therefore, our objective was to investigate the influence of $L$. buchneri as a silage additive and the F:C ratio on growth performance and meat quality of finishing feedlot beef cattle.

\section{Materials and Methods}

Ethics statement

Humane animal care and handling procedures were followed according to the Sao Paulo State University's Animal Care Committee (Project no. 012580/10).

\section{Ensiling procedure}

A flint corn - Zea mays ('2B688Hx', Dow AgroSciences, Cravinhos, São Paulo, Brazil) — was harvested at $312 \mathrm{~g} \mathrm{~kg}^{-1}$ of dry matter (DM) using a Premium Flex forage harvester (Menta Mit, Cajuru, São Paulo, Brazil) and chopped to a theoretical chop length of $10 \mathrm{~mm}$. Forage was treated with water $\left(0.7 \mathrm{~L}\right.$ tonne $(\mathrm{t})^{-1}$; untreated) or $1 \times 10^{5}$ colony-forming units (cfu) of L. buchneri NCIMB 40788 (Lallemand Animal Nutrition, Milwaukee, WI, USA) per gram of fresh forage. The application level was verified by dilution plating on Man, Rogosa, and Sharpe agar (MRS, Oxoid Ltd., Unipath, Basingstoke, $\mathrm{UK})$. The inoculant was dissolved in water $\left(0.7 \mathrm{~L} \mathrm{t}^{-1}\right)$ and sprayed on fresh forage during the silo filling. Two bunker silos were filled on the same day with $60 \mathrm{t}$ of corn forage each at a packing density of $530 \mathrm{~kg} \mathrm{~m}^{-3}$ (fresh matter basis). To avoid a possible cross contamination, untreated silage was ensiled first followed by inoculated silage. Once the silage mass reached approximately 1-m height, 12 net bags with fresh well-mixed forage $(\sim 5 \mathrm{~kg})$ and known DM content (Ashbell and Weinberg 1992) were placed on the top of the silos. An additional $0.5-\mathrm{m}$ forage was then placed on the top of each silo. Silos were sealed with black-on-white polyethylene film (200 $\mu \mathrm{m}$ thick) (COPLANA, Jaboticabal, São Paulo, Brazil). Twelve fresh samples of corn forage were collected as the silos were filled to determine the chemical composition.

The ambient temperature averaged $23.2 \pm 1.6^{\circ} \mathrm{C}$ over the 70-d storage period. Approximately $9 \mathrm{~cm} \mathrm{~d}^{-1}$ of silage was removed from the face of each silo to provide forage for the bulls. The silage was removed from the silo face using a fork, and implanted bags were recovered for measurement of DM recovery as they were encountered. Each bag was immediately weighed and sampled to estimate DM content of the silage that it contained. Silage samples were collected weekly and stored at $-20^{\circ} \mathrm{C}$ for subsequent analyses.

\section{Animal performance study}

Twenty-eight Nellore bulls ( $323 \pm 10.2 \mathrm{~kg}$ ) were housed randomly in individual stalls $\left(8 \mathrm{~m}^{2}\right)$ located in a well-ventilated covered feedlot, with each stall being equipped with a feed bunk and water trough. The trial was a 2 
(corn silage untreated or treated with L. buchneri) $\times 2$ (two forage:concentrate ratio (F:C), 60:40 and 40:60, on DM basis) factorial arrangement. Diets consisted of (1) untreated silage and low concentrate $\left(400 \mathrm{~g} \mathrm{~kg}^{-1}\right.$ of $\left.\mathrm{DM}, 60: 40 \mathrm{~F}: \mathrm{C} \_\mathrm{U}\right)$; (2) inoculated silage and low concentrate (400 $\mathrm{g} \mathrm{kg}^{-1}$ of DM, 60:40 F:C_I); (3) untreated silage and moderately high concentrate $\left(600 \mathrm{~g} \mathrm{~kg}^{-1}\right.$ of DM, 40:60 F:C_U); and (4) inoculated silage and moderately high concentrate $\left(600 \mathrm{~g} \mathrm{~kg}^{-1}\right.$ of DM, 40:60 F:C_I). Diets were balanced to meet the nutrient requirements of beef cattle gaining $1.3 \mathrm{~kg} \mathrm{~d}^{-1}$ (National Research Council 2000; Table 1). Bulls were randomly assigned to treatment $(n=7)$, fed for ad libitum intake (approximately $10 \%$ orts) once daily (0700), and provided with free access to water. Orts were weighed daily before the morning feeding. Samples of offered feed and orts were collected twice weekly and stored at $-20{ }^{\circ} \mathrm{C}$ for later analyses. Orts were used to calculate DMI daily, and its chemical composition was also taken in consideration when digestibility was calculated.

Bulls were adapted to diets for $18 \mathrm{~d}$ with a gradual increase in concentrate levels during this period. The initial and final body weights (BWs) were measured after a 16-h fast, and average daily gain (ADG) was calculated by subtracting initial BW from the final BW and dividing the difference by the trial duration of $116 \mathrm{~d}$. The gain efficiency (gain:feed) was determined by dividing ADG by DMI.

\section{Digestibility study}

In vivo apparent digestibility was calculated indirectly using indigestible neutral detergent fiber (iNDF) as a marker to estimate fecal output (Valente et al. 2011). Fecal grab samples were collected from each bull every $26 \mathrm{~h}$ from days 71 to 73 (Pina et al. 2006). Samples of silage, concentrate, and refusals were also collected daily. The fecal output and in vivo apparent digestibility were calculated as follows:

$$
\text { Fecal yield }=\text { iNDF intake }(g) / \text { iNDF fecal }(\%) \times 100
$$

$$
\begin{aligned}
\text { Apparent digestibility }= & {[\mathrm{DMI}(\mathrm{g})-\text { fecal yield }(\mathrm{g})] / } \\
& {[\mathrm{DMI}(\mathrm{g})] \times 100 . }
\end{aligned}
$$

\section{Slaughter, carcass trait data collection, and sampling procedures}

Bulls (final BW: $503 \pm 23.9 \mathrm{~kg}$ ) were slaughtered after $116 \mathrm{~d}$; the carcass was split into two parts; and hot carcass weight was measured. All carcasses were refrigerated at $4{ }^{\circ} \mathrm{C}$ for approximately $24 \mathrm{~h}$ prior to estimating chilled carcass weight. The difference between chilled carcass weight and hot carcass weight was used to estimate carcass shrink. Carcass yield was calculated by dividing hot carcass weight by fasted BW and multiplying by 100 .

The final $\mathrm{pH}$ was measured after a 24 -h postmortem chill (Lage et al. 2014b) on the left side of each carcass using a $\mathrm{pH}$ meter with a penetrating electrode (model SG2 - ELK, Seven $\mathrm{Go}^{\mathrm{TM}}$, Mettler Toledo International Inc.) at a depth of $4 \mathrm{~cm}$ in the longissimus muscle at the 12th rib. The 12th rib fat thickness (RFT) and 12th rib longissimus muscle area (LMA) were also recorded (Greiner et al. 2003).

The longissimus muscle was completely removed from the left side of each carcass and three $2.54-\mathrm{cm}$-thick standardized steak samples were collected for Warner-Bratzler shear force (WBSF) analysis [American Meat Science Association (AMSA) 1995]. These same samples were also used to estimate thawing and cooking losses (CL). All longissimus muscle samples were vacuum packaged and kept at $-20{ }^{\circ} \mathrm{C}$ for $10 \mathrm{~d}$ prior to analyses.

\section{Warner-Bratzler shear force measurement}

Steaks were thawed at $4{ }^{\circ} \mathrm{C}$ for $24 \mathrm{~h}$ and oven broiled in an electric oven at $150{ }^{\circ} \mathrm{C}$. The internal steak temperature was monitored using a digital thermometer attached to a 20-gauge copper-constantan thermocouple (Omega Engineering, Stamford, CT) implanted in the center of each steak. When the internal steak temperature reached $35{ }^{\circ} \mathrm{C}$, the steak was turned and allowed to reach an internal temperature of $70{ }^{\circ} \mathrm{C}$ before removal from the oven. The cooked WBSF steaks were cooled for $24 \mathrm{~h}$ at $4{ }^{\circ} \mathrm{C}$ (AMSA 1995). Two round cores $(1.27 \mathrm{~cm}$ in diameter) were removed from each steak, with six round cores collected for each bull (three 2.54-cm-thick steaks per bull and two round cores per steak) parallel to the long axis of the muscle fibers (AMSA 1995). Each core was sheared once perpendicular to the fiber direction using a Warner-Bratzler shear machine (G-R Manufacturing Company, Manhattan, KS, USA).

\section{Steak thawing and cooking loss}

For evaluation of thawing losses, each steak was weighed frozen and after $24 \mathrm{~h}$ of thawing at $4{ }^{\circ} \mathrm{C}$. The $\mathrm{CL}$ of each steak was recorded after steaks were oven broiled during processing for WBSF. The CL was calculated as the difference between the weight of the steaks before and after oven broiling. The total CL minus drip loss represented evaporative loss. The total liquid loss was calculated by the difference between the weights of frozen and cooked steaks.

\section{Meat appearance}

For the determination of meat color, a Minolta Chroma Meter CR-300 colorimeter was used to measure the $\mathrm{L}^{*} \mathrm{a}^{*} \mathrm{~b}^{*}$ space. In this space, $\mathrm{L}^{*}$ indicates brightness, and $\mathrm{a}^{*}$ and $\mathrm{b}^{*}$ are the chromaticity coordinates as follows: the axis that runs from $-\mathrm{a}^{*}$ to $+\mathrm{a}^{*}$ varies from green to red, and the axis that runs from $-b^{*}$ to $+b^{*}$ varies between blue and yellow. A transversal cut was made through the muscle $30 \mathrm{~min}$ prior to readings to expose the myoglobin to oxygen (Abularach et al. 1998).

For the determination of thiobarbituric acid (TBA) reactive substances, meat samples ( $50 \mathrm{~g}$ ) were collected 
Table 1. Ingredient proportions, chemical composition, and fatty acid profiles of highand low-concentrate total mixed rations [60:40 and 40:60 forage:concentrate ratios (F:C)] containing untreated or inoculated corn silages. ${ }^{a}$

\begin{tabular}{|c|c|c|c|c|}
\hline & \multicolumn{2}{|l|}{ 60:40 F:C } & \multicolumn{2}{|l|}{ 40:60 F:C } \\
\hline & Untreated & Inoculated & Untreated & Inoculated \\
\hline \multicolumn{5}{|c|}{ Ingredient proportions $\left(\mathrm{g} \mathrm{kg}^{-1}\right)$ of dry matter } \\
\hline Corn silage & 600.0 & 600.0 & 400.0 & 400.0 \\
\hline Ground corn & 308.4 & 308.4 & 492.8 & 492.8 \\
\hline Soybean meal & 62.9 & 62.9 & 69.0 & 69.0 \\
\hline Minerals & 18.7 & 18.7 & 28.2 & 28.2 \\
\hline Urea & 10.0 & 10.0 & 10.0 & 10.0 \\
\hline Total & 1000 & 1000 & 1000 & 1000 \\
\hline \multicolumn{5}{|c|}{ Chemical composition of the offered diet $\left(\mathrm{g} \mathrm{kg}^{-1}\right)$ of dry matter } \\
\hline Dry matter & 506 & 512 & 616 & 621 \\
\hline Organic matter & 939 & 940 & 933 & 933 \\
\hline Crude protein & 141 & 142 & 147 & 148 \\
\hline Ether extract & 43.4 & 42.2 & 47.8 & 47.0 \\
\hline Total carbohydrates & 780 & 781 & 765 & 765 \\
\hline Nonfiber carbohydrates & 520 & 536 & 551 & 561 \\
\hline Neutral detergent fiber & 283 & 265 & 229 & 217 \\
\hline Acid detergent fiber & 158 & 144 & 121 & 111 \\
\hline \multicolumn{5}{|c|}{ Chemical composition of the consumed diet $\left(\mathrm{g} \mathrm{kg}^{-1}\right)$ of dry matter } \\
\hline Organic matter & 971 & 970 & 980 & 974 \\
\hline Crude protein & 124 & 123 & 124 & 126 \\
\hline Ether extract & 45.9 & 45.9 & 51.9 & 50.4 \\
\hline Total carbohydrates & 800 & 801 & 803 & 797 \\
\hline Nonfiber carbohydrates & 517 & 522 & 560 & 565 \\
\hline Neutral detergent fiber & 279 & 271 & 236 & 225 \\
\hline Acid detergent fiber & 148 & 135 & 119 & 107 \\
\hline \multicolumn{5}{|c|}{ Fatty acid profile of the offered $\operatorname{diet}\left(\mathrm{g} \mathrm{kg}^{-1}\right)$} \\
\hline C14:0 (myristic) & 2.21 & 1.89 & 1.65 & 1.44 \\
\hline C15:0 (pentatonic) & 0.27 & 0.35 & 0.19 & 0.24 \\
\hline C16:0 (palmitic) & 158 & 149 & 148 & 141 \\
\hline C16:1 (palmitoleic) & 1.38 & 1.47 & 1.33 & 1.39 \\
\hline C17:0 (margaric) & 1.70 & 1.34 & 1.39 & 1.15 \\
\hline C17:1 (cis-10-heptadecanoic) & 0.451 & 0.436 & 0.476 & 0.466 \\
\hline C18:0 (stearic) & 28.4 & 28.3 & 27.2 & 27.2 \\
\hline C18:1 n-9 (oleic) & 294 & 302 & 302 & 307 \\
\hline C18:1 n-7 (vaccenic) & 6.35 & 6.68 & 6.31 & 6.53 \\
\hline C18:2 n-6 (linoleic) & 413 & 422 & 423 & 428 \\
\hline C18:3 n-3 (linolenic) & 6.09 & 6.06 & 7.76 & 7.74 \\
\hline C20:0 (arachidic) & 7.61 & 8.89 & 7.14 & 7.99 \\
\hline C20:1 n-9 (5-eicosanoic) & 3.46 & 4.60 & 3.31 & 4.07 \\
\hline C22:0 (docosanoic) & 4.05 & 3.63 & 3.43 & 3.15 \\
\hline C23:0 (tricosaenoic) & 0.966 & 0.681 & 0.698 & 0.508 \\
\hline C24:0 (lignoceric) & 12.5 & 9.68 & 8.98 & 7.11 \\
\hline
\end{tabular}

and vacuum packaged in polyethylene bags. A $10 \mathrm{~g}$ sample was ground in a multiprocessor, and then $0.2 \mathrm{~mL}$ of antioxidant BHT (0.03\%) was added along with $50 \mathrm{~mL}$ of distilled water and $1 \mathrm{~mL}$ of antifoaming solution (Sigma A5758, São Paulo, Brazil). The samples were reground and homogenized for $1 \mathrm{~min}$. After homogenization, the samples were transferred to a $250-\mathrm{mL}$ volumetric flask containing pieces of porcelain, and $50 \mathrm{~mL}$ of $4 \mathrm{M}$ $\mathrm{HCl}$ solution was added. Subsequently, the samples were distilled in a blanket heater at $100{ }^{\circ} \mathrm{C}$ until $50 \mathrm{~mL}$ 
of the distillate was collected. From the distillate, $5 \mathrm{~mL}$ was transferred to a test tube, and $5 \mathrm{~mL}$ of $0.02 \mathrm{M}$ TBA solution was then added. Test tubes were placed in a boiling water bath for $35 \mathrm{~min}$. Tubes were cooled under tap water, and the absorbance was measured at $538 \mathrm{~nm}$ with a spectrophotometer. The TBA reactive substances were expressed as $\mathrm{mg}$ of malonaldehyde per kilogram of meat as described by Oliveira et al. (2011).

\section{Fatty acid profile}

Samples of the transversal section were collected from the longissimus muscle, freeze dried, and frozen for later lipid extraction and determination of free fatty acids (FFAs). Lipids were extracted using a mixture of chloroform-methanol (Bligh and Dyer 1959), and the fatty acid methyl esters (FAME) were obtained by the ISO 5509 method (International Organization for Standardization 1978) using $n$-hexane, methanol, and KOH. A mixed standard (C4-C24, Sigma-Aldrich, São Paulo, Brazil) was used to quantify individual fatty acids. Qualitative and quantitative measurements of fatty acid content were performed by chromatography using a Shimadzu gas chromatograph (model GC-14B with a Communication Bus ModuleCBM 102, Kyoto, Japan) equipped with a flame ionization detector (FID) and fused silica capillary column (Omegawax 250, Sigma-Aldrich, São Paulo, Brazil). The column was $30 \mathrm{~m}$ in length with a diameter of $0.25 \mathrm{~mm}$ and a film thickness of $0.25 \mu \mathrm{m}$ (Supelco SP-24136, Sigma-Aldrich, São Paulo, Brazil). Helium was used as the carrier gas at a flow of $1 \mathrm{~mL} \mathrm{~min}{ }^{-1}$. Fatty acid analysis was performed by autoinjection of $1 \mu \mathrm{L}$ of each sample at a "split" at a division ratio of $1 / 100$ and temperature of $250{ }^{\circ} \mathrm{C}$. The temperature of the oven was programmed to remain at $100{ }^{\circ} \mathrm{C}$ for $2 \mathrm{~min}$ and then increase to $220^{\circ} \mathrm{C}$ at $4{ }^{\circ} \mathrm{C} \mathrm{min}^{-1}$ for $25 \mathrm{~min}$, while the detector was maintained at $280^{\circ} \mathrm{C}$. The identification and quantification of fatty acid methyl esters were achieved by a comparison with the retention times and concentrations of fatty acid methyl esters in the standard.

\section{Determination of ruminal fermentation products}

Four ruminally cannulated Nellore bulls (initial $\mathrm{BW}=487 \pm 48.4 \mathrm{~kg}$ ), each fitted with a silicone, 10.2-cm ruminal cannula, were used in as a $4 \times 4$ Latin square experiment. Each animal was housed individually in a pen $\left(8 \mathrm{~m}^{-2}\right)$, fitted with individual feed bunks and water bowls. Bulls were fed for ad libitum intake once a day $(0700)$, and diets used were the same as those used in the feedlot program.

Ruminal measurements were taken over four 10-d periods, with each period consisting of $9 \mathrm{~d}$ to adapt to the diets and $1 \mathrm{~d}$ for ruminal fluid collection. A 50-mL sample of ruminal fluid was collected from the reticulum and ventral, caudal, and dorsal-ventral sacs of the reticulorumen of each bull before feeding $(0 \mathrm{~h})$ and at $3,6,9$, and $12 \mathrm{~h}$ after feeding. Ruminal fluid was squeezed through two layers of cheesecloth and the $\mathrm{pH}$ was immediately measured. Subsequently, $1 \mathrm{~mL}$ $\mathrm{H}_{2} \mathrm{SO}_{4}$ (1:1) was added to the ruminal fluid, and the solution was stored at $-20^{\circ} \mathrm{C}$ for analyses of ammonia-N and volatile fatty acids (VFAs).

\section{Chemical analyses}

A water extract was produced from fresh silage samples as described by Kung et al. (1984), and silage $\mathrm{pH}$ was measured (MA522 model, Marconi Laboratory Equipment, Piracicaba, Sao Paulo, Brazil). The VFAs were measured using a gas chromatograph (GC2014, Shimadzu Corporation, Kyoto, Japan) equipped with a HP-INNOWax capillary column $(30 \mathrm{~m} \times 0.32 \mathrm{~mm}$; Agilent Technologies, Colorado, USA) at an initial temperature of $80^{\circ} \mathrm{C}$ for $3 \mathrm{~min}$ followed by a heating rate of $20{ }^{\circ} \mathrm{C} \mathrm{min}-1$ until a final temperature of $240{ }^{\circ} \mathrm{C}$ was achieved. Lactic acid was determined using a colorimetric method (Barker and Summerson 1941), and ammonia-N was measured by distillation [Association of Official Analytical Chemists (AOAC) 1996; method no. 941.04]. The FFAs in silages were measured using the same procedure as described for meat samples. The $\mathrm{pH}$ and ammonia-N of ruminal fluid were analyzed as described for silage, whereas VFAs were analyzed in the supernatant after centrifugation at $4{ }^{\circ} \mathrm{C}$ and $20000 \mathrm{~g}$ for $30 \mathrm{~min}$.

Feed, orts, and feces were oven dried $\left(55{ }^{\circ} \mathrm{C}\right.$ for $\left.72 \mathrm{~h}\right)$ and processed in a knife mill (Basso et al. 2014) before being ground through a 1-mm screen and analyzed for DM $\left(105{ }^{\circ} \mathrm{C}\right.$ for $\left.12 \mathrm{~h}\right)$ and ash $\left(500{ }^{\circ} \mathrm{C}\right.$ for $\left.5 \mathrm{~h}\right)$. Neutral detergent fiber (NDF) was determined using a heat stable amylase and corrected for ash and protein. The acid detergent fiber (ADF) content was corrected for ash. Both were determined in an Ankom 2000 Fiber Analyzer (Ankom Technologies, Macedon, NY, USA) without sodium sulfite (Van Soest et al. 1991). Separate samples were used for NDF and ADF analyses, and both samples included residual N. Lignin was sequentially measured after hydrolysis of the ADF residual in $72 \%$ $\mathrm{H}_{2} \mathrm{SO}_{4}$ (Van Soest and Robertson 1985). Ether extract (EE) also was determined using method no. 920.39 (AOAC 1996). The analysis of $\mathrm{N}$ in the NDF and ADF residuals, feed, and feces was performed by rapid combustion using a Leco F528 $\mathrm{N}$ analyzer (LECO Corporation, St. Joseph, MI, USA). Crude protein (CP) was calculated as total $\mathrm{N} \times 6.25$ (AOAC 1996; method no. 930.15). Total carbohydrate and nonfiber carbohydrate (NFC) concentrations were calculated as described by Sniffen et al. (1992).

For microbiological analyses, silage $(25 \mathrm{~g})$ from each replicate was homogenized in $225 \mathrm{~mL}$ saline solution $(\mathrm{NaCl} 0.85 \%)$ for $1 \mathrm{~min}$. An aliquot $(1 \mathrm{~mL})$ was plated on plates containing potato dextrose agar (PDA) after serial dilutions of $10^{-1}$ to $10^{-9}$. The PDA plates were incubated at $28{ }^{\circ} \mathrm{C}$, and yeasts and molds were counted after 2 and $5 \mathrm{~d}$, respectively. 
Table 2. Chemical composition, fermentation, and microbiological profiles of corn silage (mean \pm standard error) either untreated or inoculated with Lactobacillus buchneri $(n=12){ }^{a}$

\begin{tabular}{|c|c|c|}
\hline Item & Untreated & Inoculated $^{b}$ \\
\hline \multicolumn{3}{|c|}{ Chemical composition $\left(\mathrm{g} \mathrm{kg}^{-1}\right)$ of dry matter } \\
\hline Dry matter & $315 \pm 5.4$ & $326 \pm 5.0$ \\
\hline Crude protein & $82.3 \pm 1.73$ & $84.3 \pm 1.81$ \\
\hline Neutral detergent fiber (NDF) & $353 \pm 4.8$ & $328 \pm 5.26$ \\
\hline Indigestible NDF ( $\mathrm{g} \mathrm{kg}^{-1}$ of NDF) & $388 \pm 9.8$ & $406 \pm 16.2$ \\
\hline Acid detergent fiber & $230 \pm 3.7$ & $207 \pm 3.48$ \\
\hline Cellulose & $190 \pm 3.3$ & $172 \pm 1.89$ \\
\hline Hemicellulose & $159 \pm 5.0$ & $153 \pm 4.52$ \\
\hline Lignin (sa) & $28.8 \pm 1.71$ & $25.5 \pm 1.60$ \\
\hline $\mathrm{ADIN}^{c}$ ( $\mathrm{g} \mathrm{kg}^{-1}$ of total nitrogen) & $125 \pm 4.2$ & $115 \pm 6.85$ \\
\hline Total carbohydrates & $844 \pm 2.2$ & $843 \pm 2.73$ \\
\hline Nonfiber carbohydrates & $491 \pm 5.5$ & $514 \pm 6.61$ \\
\hline \multicolumn{3}{|c|}{ Fermentation profile $\left(\mathrm{g} \mathrm{kg}^{-1}\right)$ of dry matter } \\
\hline Dry matter recovery & $905 \pm 23.8$ & $889 \pm 12.9$ \\
\hline Lactic acid & $106 \pm 11.8$ & $74.7 \pm 5.31$ \\
\hline Acetic acid & $61.4 \pm 3.43$ & $61.0 \pm 2.00$ \\
\hline Lactic acid:acetic acid & $1.80 \pm 0.179$ & $1.24 \pm 0.085$ \\
\hline $\mathrm{pH}$ & $3.60 \pm 0.014$ & $3.60 \pm 0.012$ \\
\hline Ammonia-N ( $\mathrm{g} \mathrm{kg}^{-1}$ of total nitrogen) & $50.5 \pm 0.43$ & $43.5 \pm 0.43$ \\
\hline \multicolumn{3}{|c|}{ Microbiological profile $\left(\mathrm{cfu}^{-1}\right)$ of fresh silage } \\
\hline Yeasts & $4.04 \pm 0.336$ & $3.09 \pm 0.087$ \\
\hline Moulds & $2.91 \pm 0.021$ & $2.41 \pm 0.056$ \\
\hline \multicolumn{3}{|c|}{$\begin{array}{l}{ }^{a} \text { Silage samples collected during feed out. } \\
{ }^{b} \text { Corn silage untreated or inoculated with Lactobacillus buchneri } \\
\text { NCIMB } 40788 \text { at the application rate } 1 \times 10^{5} \mathrm{cfu}^{-1} \text { of fresh forage } \\
\text { (Lallemand Animal Nutrition, Milwaukee, WI, USA). } \\
{ }^{c} \text { Acid detergent insoluble nitrogen. }\end{array}$} \\
\hline
\end{tabular}

\section{Statistical analyses}

All microbiological data were log transformed. Growth performance, digestibility, carcass, and meat traits were analyzed using PROC MIXED of SAS (v. 9.0, SAS Institute Inc., Cary, NC) as a completely randomized design with a $2 \times 2$ factorial arrangement (with seven replicates) of treatments. Diet was considered as a fixed effect and error as a random effect. The following general model was used:

$$
Y_{i j k}=\mu+S_{i}+C_{j}+S C_{i j}+W_{X i j}+e_{i j k}
$$

where $Y_{i j k}=$ response variable; $\mu=$ overall mean; $S=$ effect of silage $i$; $C=$ effect of $\mathrm{F}: \mathrm{C}$ ratio $j$; $S C=$ effect of interaction between silage $i$ and $\mathrm{F}: \mathrm{C}$ ratio $j$; and $W_{X i j}=$ initial live weight, used as a covariate for variables regarding growth performance, digestibility, carcass, and meat traits; and $e_{i j k}=$ error term. A simple $4 \times 4$ Latin square design was carried out to measure ruminal parameters being evaluated as repeated measurements over time. All data were analyzed using PROC MIXED of SAS (v. 9.0, SAS Institute Inc., Cary, NC). Several covariance structures were tested (ANTE(1), AR(1), ARH(1), ARMA(1,1), CS, CSH, FA0(1), FA(1), HF, SIMPLE, TOEP, TOEPH, UN, UNAR, UNCS, and VC) and those that generated the lowest Akaike information criterion were selected. Diet was considered as a fixed effect, and animal and Latin square were considered as random effect.

Differences among means were determined using an $F$ test, whereas significant means for growth performance, digestibility, ruminal parameters, carcass, and meat traits were compared using the PDIFF option of LSMEANS. When significant interactions occurred, means were separated using a Fisher's F-protected least significant difference test. Data of initial live weight were included as a covariate. Significant differences were declared at $P \leq 0.05$ and trends at $P>0.05 \leq 0.10$.

\section{Results}

Chemical composition, fermentation, and fatty acid profiles of corn silage

Inoculated silages had less NDF, ADF, and lactic acid content, as well as numbers of yeasts and molds, than untreated silage (Table 2). Inoculated silages had lesser levels of palmitic, margaric, and lignoceric acids, as well as total SFA, compared with untreated silages (Table 3).

Feed intake, digestibility, growth performance, and carcass characteristics of bulls

Interactions $(P<0.01)$ between inoculation and $F: C$ ratio occurred for intake of DM, CP, EE, and NDF 
Table 3. Fatty acids profile (mean \pm standard error) of corn silage either untreated or inoculated with Lactobacillus buchneri $(n=12) .{ }^{a}$

\begin{tabular}{|c|c|c|}
\hline Fatty acid $\left(\mathrm{g} \mathrm{kg}^{-1}\right)$ & Untreated & Inoculated $^{b}$ \\
\hline C12:0 (lauric) & $2.83 \pm 0.038$ & $2.25 \pm 0.050$ \\
\hline C14:0 (myristic) & $3.45 \pm 0.075$ & $2.80 \pm 0.088$ \\
\hline C15:0 (pentatonic) & $0.50 \pm 0.038$ & $0.50 \pm 0.019$ \\
\hline C16:0 (palmitic) & $179 \pm 0.8$ & $162 \pm 1.3$ \\
\hline C16:1 (palmitoleic) & $1.35 \pm 0.088$ & $1.75 \pm 0.063$ \\
\hline C17:0 (margaric) & $2.30 \pm 0.019$ & $1.70 \pm 0.075$ \\
\hline C17:1 (cis-10-heptadecanoic) & $0.45 \pm 0.025$ & $0.40 \pm 0.038$ \\
\hline C18:0 (stearic) & $31.1 \pm 0.375$ & $30.1 \pm 0.156$ \\
\hline C18:1 n-9 (oleic) & $296 \pm 1.4$ & $305 \pm 3.6$ \\
\hline C18:1 n-7 (vaccenic) & $7.50 \pm 0.775$ & $6.20 \pm 0.125$ \\
\hline C18:2 n-6 (linoleic) & $387 \pm 3.9$ & $409 \pm 4.5$ \\
\hline C18:3 n-6 ( $\gamma$-linolenic) & $45.7 \pm 0.90$ & $39.4 \pm 2.98$ \\
\hline C18:3 n-3 (linolenic) & $0.50 \pm 0.150$ & $0.80 \pm 0.025$ \\
\hline C20:0 (arachidic) & $8.95 \pm 0.219$ & $11.2 \pm 1.39$ \\
\hline C20:1 n-9 (5-eicosanoic) & $5.45 \pm 0.950$ & $5.85 \pm 1.150$ \\
\hline C22:0 (docosanoic) & $4.75 \pm 0.094$ & $4.45 \pm 0.050$ \\
\hline C23:0 (tricosanoic) & $1.05 \pm 0.125$ & $0.945 \pm 0.0750$ \\
\hline C24:0 (lignoceric) & $20.8 \pm 0.06$ & $14.8 \pm 0.04$ \\
\hline $\mathrm{SFA}^{c}$ & $255 \pm 1.9$ & $230 \pm 2.7$ \\
\hline MUFA $^{d}$ & $310 \pm 3.1$ & $320 \pm 4.8$ \\
\hline PUFA $^{e}$ & $435 \pm 5.0$ & $450 \pm 7.5$ \\
\hline
\end{tabular}

${ }^{a}$ Silage samples collected during feed-out.

${ }^{b}$ Corn silage untreated or inoculated with Lactobacillus buchneri NCIMB 40788 at the application rate $1 \times 10^{5} \mathrm{cfu} \mathrm{g}^{-1}$ of fresh forage (Lallemand Animal Nutrition, Milwaukee, WI, USA).

'Saturated fatty acids: C12:0, C14:0, C15:0, C16:0, C17:0, C18:0, C20:0, C22:0, C23:0, and C24:0.

${ }^{d}$ Monounsaturated fatty acids: C16:1, C17:1, C18:1 n-9, C18:1 n-7, and C20:1 n-9.

${ }^{e}$ Polyunsaturated fatty acids: C18:2 n-6, C18:3 n-6, and C18:3 n-3.

(Table 4). Bulls fed the 40:60 F:C_I diet had DMIs that were $1.03,1.05$, and $1.24 \mathrm{~kg}$ greater $(P<0.01)$ than bulls fed the 60:40 F:C_U, 60:40 F:C_I, and 40:60 F:C_U diets, respectively. Likewise, the intakes of $\mathrm{CP}$ and $\mathrm{EE}$ were also greater $(P<0.01)$ for bulls fed the inoculated silage and high amount of concentrate (ISHC) diet compared with all other diets. The 60:40 F:C_U diet resulted in greater $(P=0.002)$ NDF intake, which was $0.37,0.13$, and $0.23 \mathrm{~kg}$ more than for bulls fed 60:40 F:C_I, 40:60 F:C_U, and 40:60 F:C_I diets, respectively.

Inoculation reduced $(P=0.02) \mathrm{DM}$ digestibility by $19 \mathrm{~g} \mathrm{~kg}^{-1}$ compared with bulls fed diets composed of untreated silage (Table 4). Bulls fed the 40:60 F:C ratio had a slight increase in EE digestibility $(P=0.02)$. An interaction $(P=0.009)$ between inoculation and $\mathrm{F}: \mathrm{C}$ ratio was observed for NDF digestibility. Bulls fed diets composed of inoculated silages had lesser NDF digestibility, but inoculation reduced it mainly when they were fed with the 60:40 F:C ratio. In addition, bulls fed the 40:60 F:C ratio had greater $(P<0.01)$ NDF digestibility compared with bulls fed the 60:40 F:C ratio.
An interaction $(P=0.029)$ between inoculation and $\mathrm{F}: \mathrm{C}$ ratio was observed for ADG (Table 4). Bulls fed the 40:60 F:C_I diet had greater ADG than bulls fed the 60:40 F:C_U, 60:40 F:C_I, and 40:60 F:C_U diets (8\%, 10\%, and $16 \%$ increases in $\mathrm{ADG}$, respectively). In addition, an interaction $(P=0.007)$ between inoculation and $\mathrm{F}: \mathrm{C}$ ratio was also observed for LMA, with bulls fed the 60:40 F:C_U and 40:60 F:C_I diets having larger $(P=0.007)$ LMA compared with bulls fed the 60:40 F:C_I and 40:60 F:C_U diets.

\section{Ruminal parameters}

Inoculation of corn silage with L. buchneri tended $(P=0.08)$ to reduce ruminal fluid $\mathrm{pH}$ only when bulls were fed with the 60:40 F:C ratio (Table 5). Ammonia-N was unaffected by treatment $(P>0.05)$. There was a trend $(P<0.10)$ for an increase in total VFA in bulls fed the 40:60 F:C ratio diet (43.8 vs. $35.5 \mathrm{mmol} \mathrm{L}^{-1}$ in bulls fed the $60: 40 \mathrm{~F}: \mathrm{C}$ ratio diet). There was an interaction $(P<0.01)$ between silage and $F: C$ ratio for acetic acid and propionic acid concentrations, as well as acetic acid:propionic acid. Inoculation of corn silage reduced $(P=0.009)$ acetic acid concentration and increased $(P=0.002)$ propionic acid concentration when bulls were fed the 40:60 F:C ratio diet compared with the 60:40 F:C diet. As a consequence, acetic acid:propionic acid was lower $(P<0.01)$ in ruminal fluid of bulls fed the 40:60 F:C_I diet. Inoculation of corn silage increased $(P=0.008)$ the concentration of butyric acid from 10.2 (untreated silage) to $11.4 \mathrm{mmol} \mathrm{L}^{-1}$ compared with untreated silage. Butyric acid increased $(P=0.02)$ when bulls were fed the 40:60 F:C diet in comparison with the 60:40 F:C diet (11.3 vs. $10.3 \mathrm{mmol} \mathrm{L}^{-1}$, respectively).

\section{Meat traits and fatty acids profile}

Inoculation of corn silage tended $(P=0.064)$ to reduce the concentration of TBA in the meat by $9 \%$ (Table 6 ). In addition, the concentration of TBA was affected $(P<0.01)$ by F:C ratio, with bulls fed the 60:40 F:C diet having a $15 \%$ greater TBA $\left(0.39 \mathrm{mg} \mathrm{TPM} \mathrm{g}^{-1}\right)$ than those fed the 40:60 F:C diet. Neither inoculation nor F:C ratio affected drip or defrost losses $(P>0.05)$, but bulls fed the 40:60 F:C diet tended $(P=0.096)$ to have reduced $C L$ compared with those fed the 60:40 F:C diet. Bulls fed the 40:60 F:C diet had greater $(P=0.042)$ intensity of red color in meat compared with those fed the 60:40 $\mathrm{F}: \mathrm{C}$ diet (14.02 vs. 12.29 , respectively). There was also a trend $(P=0.074)$ for a greater intensity of yellow fat in bulls fed diets containing inoculated silages compared with those fed untreated silage (12.37 vs. 10.99).

The concentrations of pentatonic $(P=0.034)$ and palmitic $(P=0.002)$ acids in the longissimus muscle were reduced by inoculation ( $15 \%$ and $7 \%$, respectively), whereas the concentrations of oleic, arachidonic, timnodonic, docosatetraenoic, and nervonic acids increased $(P<0.05$; Table 7). Moreover, inoculation further increased $(P=0.018)$ the concentration of omega- 9 fatty 
Table 4. Effect of inoculation of corn silage with Lactobacillus buchneri (untreated vs. inoculated) and the forage:concentrate ratio (60:40 vs. 40:60 F:C) on feed intake, digestibility, growth performance, and carcass characteristics of finishing Nellore bulls fed for $116 \mathrm{~d}^{a}(n=7)$.

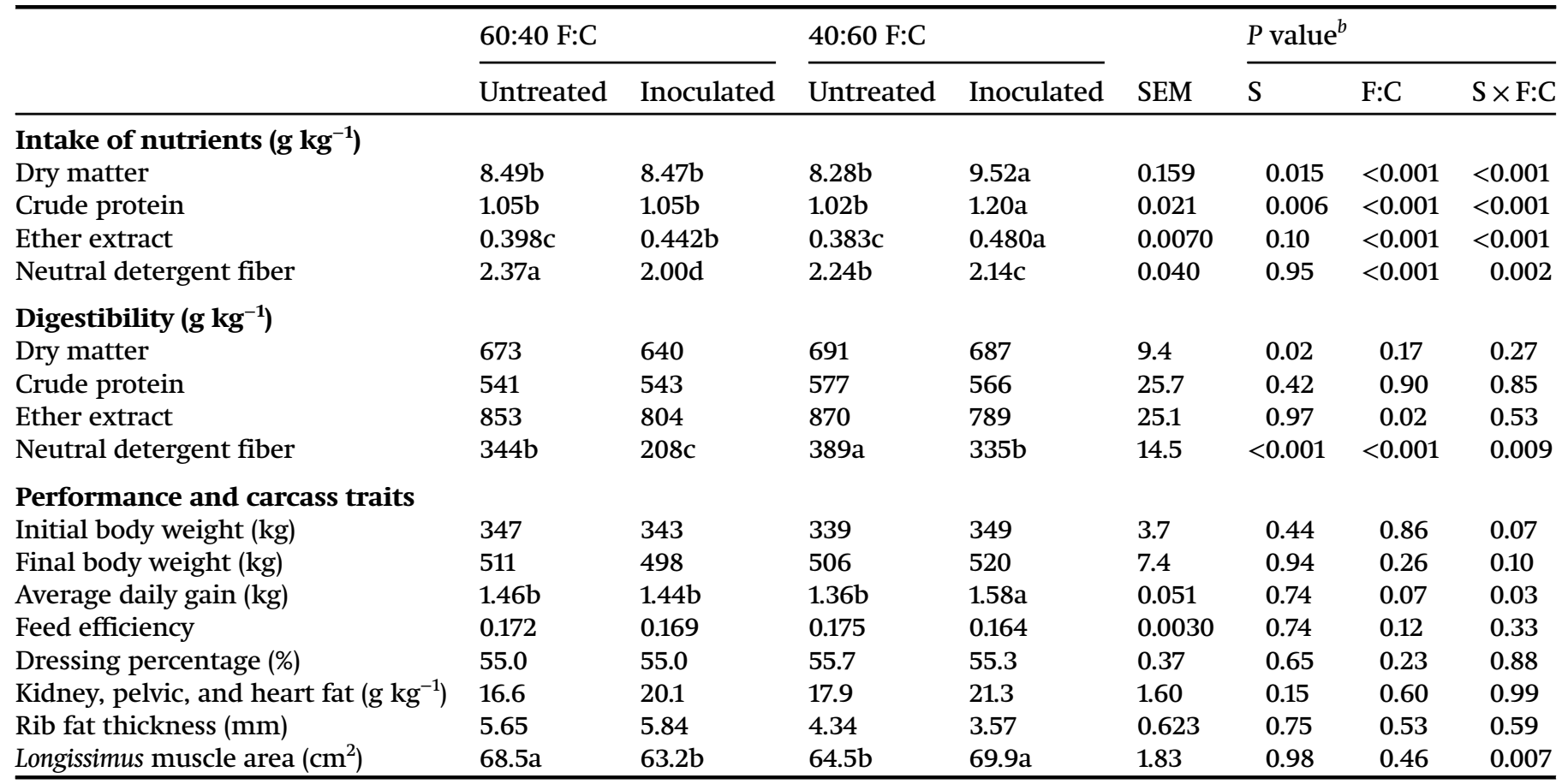

Note: Means in the same row with lowercased letters differed $(P<0.05)$.

${ }^{a}$ Diets consisted of (1) untreated silage and low concentrate (400 $\mathrm{g} \mathrm{kg}^{-1}$ of DM, 60:40 F:C_U); (2) inoculated silage and low concentrate (400 $\mathrm{g} \mathrm{kg}^{-1}$ of DM, 60:40 F:C_I); (3) untreated silage and moderately high concentrate $\left(600 \mathrm{~g} \mathrm{~kg}^{-1} \mathrm{of} \mathrm{DM,} 40: 60 \mathrm{~F}: \mathrm{C} \_\mathrm{U}\right)$; and (4) inoculated silage and moderately high concentrate $\left(600 \mathrm{~g} \mathrm{~kg}^{-1}\right.$ of DM, 40:60 F:C_I).

${ }^{b} \mathrm{~S}$, silage; F:C, forage:concentrate ratio; $\mathrm{S} \times \mathrm{F}: \mathrm{C}$, interaction between silage and forage:concentrate ratio.

Table 5. Effect of inoculation of corn silage with Lactobacillus buchneri (untreated vs. inoculated) and forage:concentrate ratio (60:40 vs. 40:60 F:C) on ruminal parameters ( $\mathrm{mmol} \mathrm{L}^{-1}$, unless otherwise stated) of Nellore bulls ${ }^{a}(n=4)$.

\begin{tabular}{|c|c|c|c|c|c|c|c|c|c|c|c|c|}
\hline & \multicolumn{2}{|l|}{$60: 40 \mathrm{~F}: \mathrm{C}$} & \multicolumn{2}{|l|}{ 40:60 F:C } & \multirow[b]{2}{*}{ SEM } & \multicolumn{7}{|c|}{$P$ value ${ }^{b}$} \\
\hline & Untreated & Inoculated & Untreated & Inoculated & & $S$ & $\mathrm{~F}: \mathrm{C}$ & $\mathrm{S} \times \mathrm{F}: \mathrm{C}$ & $\mathrm{T}$ & $\mathrm{S} \times \mathrm{T}$ & $\mathrm{F}: \mathrm{C} \times \mathrm{T}$ & $\mathrm{S} \times \mathrm{F}: \mathrm{C} \times \mathrm{T}$ \\
\hline $\mathrm{pH}$ & 6.17 & 6.02 & 6.05 & 6.00 & 0.124 & 0.08 & 0.20 & 0.32 & $<0.001$ & 0.85 & 0.64 & 0.80 \\
\hline Ammonia-N (mg dL $\left.{ }^{-1}\right)$ & 8.61 & 10.2 & 10.5 & 8.64 & 1.039 & 0.88 & 0.86 & 0.11 & 0.06 & 0.83 & 0.53 & 0.49 \\
\hline Total volatile fatty acids & 37.7 & 33.3 & 46.8 & 40.8 & 5.33 & 0.31 & 0.10 & 0.88 & 0.44 & 0.72 & 0.92 & 0.99 \\
\hline \multicolumn{13}{|c|}{ Molar proportion (mmol $100 \mathrm{mmol}^{-1}$ ) } \\
\hline Acetic acid & $71.8 \mathrm{a}$ & $72.8 \mathrm{a}$ & $71.8 \mathrm{a}$ & $67.7 \mathrm{~b}$ & 1.06 & 0.14 & $<0.001$ & 0.009 & 0.03 & 0.90 & 0.98 & 0.94 \\
\hline Propionic acid & $18.4 \mathrm{~b}$ & $16.5 c$ & $18.2 b$ & $20.3 a$ & 0.90 & 0.89 & 0.002 & $<0.001$ & 0.02 & 0.81 & 0.80 & 0.97 \\
\hline Butyric acid & 9.82 & 10.7 & 10.6 & 12.0 & 0.519 & 0.008 & 0.02 & 0.59 & 0.08 & 0.96 & 0.98 & 0.81 \\
\hline Acetic acid:propionic acid & $3.97 \mathrm{~b}$ & 4.57a & 4.10ab & $3.40 \mathrm{c}$ & 0.262 & 0.78 & 0.008 & $<0.001$ & 0.11 & 0.85 & 0.93 & 0.98 \\
\hline
\end{tabular}

Note: Means in the same row with lowercased letters differed $(P<0.05)$.

${ }^{a}$ Diets consisted of (1) untreated silage and low concentrate (400 $\mathrm{g} \mathrm{kg}^{-1}$ of DM, 60:40 F:C_U); (2) inoculated silage and low concentrate (400 $\mathrm{g} \mathrm{kg}^{-1}$ of DM, 60:40 F:C_I); (3) untreated silage and moderately high concentrate $\left(600 \mathrm{~g} \mathrm{~kg}{ }^{-1} \mathrm{of} \mathrm{DM} 40: 60 \mathrm{~F}: \mathrm{C}_{-} \mathrm{U}\right)$; and (4) inoculated silage and moderately high concentrate $\left(600 \mathrm{~g} \mathrm{~kg}^{-1}\right.$ of DM, 40:60 F:C_I).

${ }^{b} \mathrm{~S}$, silage; F:C, forage:concentrate ratio; $\mathrm{S} \times \mathrm{F}: \mathrm{C}$, interaction between silage and forage:concentrate ratio; $\mathrm{T}$, time; $\mathrm{S} \times \mathrm{T}$, interaction between silage and time; $\mathrm{F}: \mathrm{C} \times \mathrm{T}$, interaction between forage:concentrate ratio and time; $\mathrm{S} \times \mathrm{F}: \mathrm{C} \times \mathrm{T}$, interaction among silage, forage:concentrate ratio, and time.

acids (plus 7\%) and unsaturated fatty acid (UFA):SFA ratio (1.17 vs. 1.05, respectively, in bulls fed the diets composed of untreated silage). There was a trend toward increased monounsaturated fatty acid (MUFA) $(P=0.097)$ and UFA $(P=0.093)$ (plus $4 \%)$ in the meat of bulls fed diets containing inoculated corn silage. 
Table 6. Effect of inoculation of corn silage with Lactobacillus buchneri (untreated vs. inoculated) and forage:concentrate ratio (60:40 vs. 40:60 F:C) on meat traits of finishing Nellore bulls fed for $116 \mathrm{~d}^{a}(n=7)$.

\begin{tabular}{|c|c|c|c|c|c|c|c|c|}
\hline & \multicolumn{2}{|l|}{ 60:40 F:C } & \multicolumn{2}{|l|}{ 40:60 F:C } & SEM & \multicolumn{3}{|c|}{$P$ value $^{b}$} \\
\hline Meat traits & & & & & & & & \\
\hline $\mathrm{pH}$ & 5.94 & 5.93 & 6.26 & 6.08 & 0.143 & 0.56 & 0.14 & 0.59 \\
\hline Thiobarbituric acid (mg TPM g ${ }^{-1}$ ) & 0.412 & 0.373 & 0.338 & 0.315 & 0.0150 & 0.06 & $<0.001$ & 0.63 \\
\hline Warner-Bratzler shear force (kgf) & 4.04 & 4.47 & 4.09 & 3.73 & 0.482 & 0.94 & 0.48 & 0.43 \\
\hline Drip losses $\left(\mathrm{g} \mathrm{kg}^{-1}\right)$ & 33.9 & 42.6 & 37.2 & 30.2 & 5.63 & 0.88 & 0.43 & 0.18 \\
\hline \multicolumn{9}{|l|}{ Meat color } \\
\hline Luminosity (L*) & 32.7 & 33.4 & 33.4 & 34.6 & 1.10 & 0.45 & 0.42 & 0.83 \\
\hline Intensity of red $\left(\mathrm{a}^{*}\right)$ & 12.3 & 12.3 & 14.8 & 13.3 & 0.73 & 0.35 & 0.04 & 0.37 \\
\hline Intensity of yellow (b*) & 7.15 & 6.93 & 8.19 & 8.94 & 0.809 & 0.77 & 0.09 & 0.58 \\
\hline \multicolumn{9}{|l|}{ Fat color } \\
\hline
\end{tabular}

Note: Means in the same row with lowercased letters differed $(P<0.10)$.

${ }^{a}$ Diets consisted of (1) untreated silage and low concentrate (400 $\mathrm{g} \mathrm{kg}^{-1}$ of DM, 60:40 F:C_U); (2) inoculated silage and low concentrate (400 $\mathrm{g} \mathrm{kg}^{-1}$ of DM, 60:40 F:C_I); (3) untreated silage and moderately high concentrate $\left(600 \mathrm{~g} \mathrm{~kg}^{-1} \mathrm{of} \mathrm{DM} 40: 60 \mathrm{~F}: \mathrm{C}_{-} \mathrm{U}\right)$; and (4) inoculated silage and moderately high concentrate $\left(600 \mathrm{~g} \mathrm{~kg}^{-1}\right.$ of DM, 40:60 F:C_I $)$.

${ }^{b} \mathrm{~S}$, silage; $\mathrm{F}: \mathrm{C}$, forage:concentrate ratio; $\mathrm{S} \times \mathrm{F}: \mathrm{C}$, interaction between silage and forage:concentrate ratio.

The concentrations of palmitic $(P=0.032)$ and palmitoleic $(P=0.024)$ acids were lesser in meat from bulls fed the 40:60 F:C diet compared with those fed the 60:40 F:C diet (5\% and 9\%, respectively; Table 7). The concentrations of PUFA $(P=0.027)$ and omega- 6 fatty acids $(P=0.022)$ increased by $23 \%$ and $26 \%$, respectively, in bulls fed the 40:60 F:C diet compared with those fed the 60:40 F:C diet. Bulls fed 40:60 F:C diet also had a greater $(P=0.013)$ PUFA:SFA ratio compared with those fed the 60:40 F:C diet (0.11 vs. 0.08, respectively).

\section{Discussion}

Livestock diets can be favorably altered to improve meat quality of beef cattle in a manner that promotes human health (Scollan et al. 2006). In this regard, inoculation of forages with L. buchneri has been claimed to reduce the aerobic deterioration of silages (Kleinschmit and Kung 2006) by converting lactic acid into acetic acid and 1,2-propanediol (Oude Elferink et al. 2001). Lactobacillus buchneri is also able to produce antimicrobial substances such as buchnericin (Yildirim 2001), which could alter the population of Gram-positive bacteria in the rumen (Klaenhammer 1993), that are involved in the biohydrogenation of fatty acids. Furthermore, it has been shown that high-grass diets can improve meat quality by increasing PUFA:SFA ratio and CLA in the intramuscular fat of beef cattle (French et al. 2000; Nuernberg et al. 2005). Therefore, we hypothesized that the use of different $\mathrm{F}: \mathrm{C}$ ratios may alter the level of
L. buchneri administered and change the performance of beef cattle and the fatty acid composition of meat.

As expected, inoculation of corn silage decreased the lactic acid concentration and DM recovery of corn silage. Lactobacillus buchneri converts lactic acid to acetic acid and 1,2-propanediol at the point when primary fermentation is nearing completion (Oude Elferink et al. 2001). Thus, the reduction in lactic acid concentration and the reduced DM recovery in this study are in agreement with the biological role of this bacterium. Although the strain of L. buchneri used in this study possessed no fibrolytic activity, inoculated silage had a lesser NDF content. Reductions of NDF content have been previously reported in corn silages treated with L. buchneri (Arriola et al. 2011; Nkosi et al. 2011). In our study, inoculation of corn silage with L. buchneri reduced NDF content as previously described, but iNDF increased on an NDF basis. Moreover, inoculated corn silage had reduced concentrations of palmitic and margaric acids, as well as total SFA, likely due to the differences in fermentation as mediated by L. buchneri (McDonald et al. 1991; Boufaïed et al. 2003).

Bulls fed the 40:60 F:C_I diet had a greater DMI likely due to the lesser NDF and greater NFC content of inoculated corn silage. The detrimental influence of great fiber forages on feed intake has been recognized (Mertens 1977). In addition, bulls fed the 60:40 F:C_U and 40:60 F:C_U diets had greater NDF intake possibly due to the greater NDF digestibility of these diets. Inoculation of corn silage with L. buchneri decreased $\mathrm{NDF}$ digestibility for both F:C ratios, but especially when 
Table 7. Effect of inoculation of corn silage with Lactobacillus buchneri (untreated vs. inoculated) and forage:concentrate ratio (60:40 vs. 40:60 F:C) on fatty acids profile of intramuscular fat in the longissimus muscle of finishing Nellore bulls fed for $116 \mathrm{~d}^{a}(n=7)$.

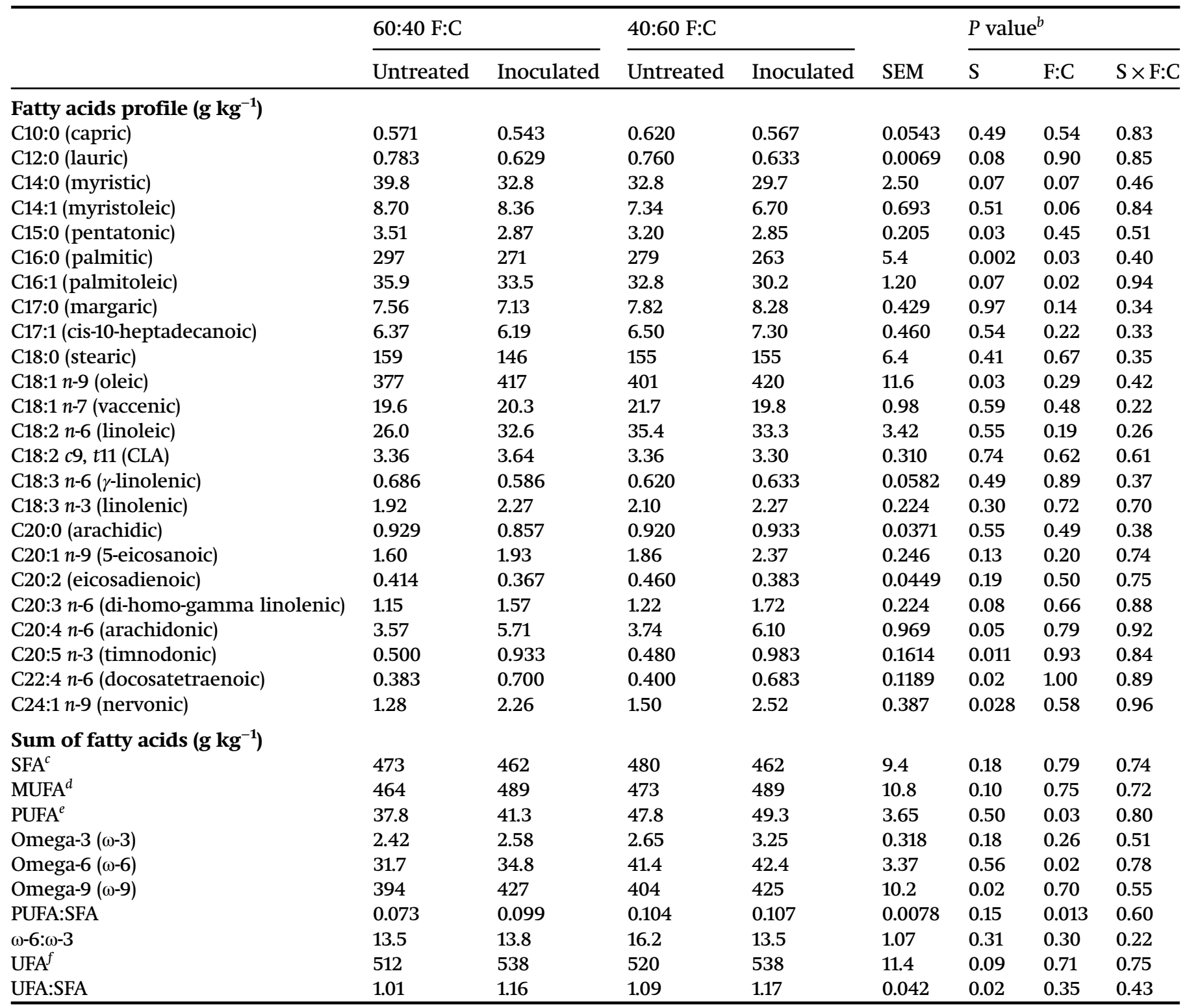

${ }^{a}$ Diets consisted of (1) untreated silage and low concentrate (400 $\mathrm{g} \mathrm{kg}^{-1}$ of DM, 60:40 F:C_U); (2) inoculated silage and low concentrate (400 $\mathrm{g} \mathrm{kg}^{-1}$ of DM, 60:40 F:C_I); (3) untreated silage and moderately high concentrate $\left(600 \mathrm{~g} \mathrm{~kg}{ }^{-1} \mathrm{of} \mathrm{DM}, 40: 60 \mathrm{~F}: \mathrm{C}_{-} \mathrm{U}\right)$; and (4) inoculated silage and moderately high concentrate $\left(600 \mathrm{~g} \mathrm{~kg}^{-1}\right.$ of DM, 40:60 F:C_I).

${ }^{b} \mathrm{~S}$, silage; $\mathrm{F}: \mathrm{C}$, forage:concentrate ratio; $\mathrm{S} \times \mathrm{F}: \mathrm{C}$, interaction between silage and forage:concentrate ratio.

'Saturated fatty acids: C10:0, C12:0, C14:0, C15:0, C16:0, C17:0, C18:0, and C20:0.

${ }^{d}$ Monounsaturated fatty acids: C14:1, C16:1, C18:1 n-9, C18:1 n-7, C20:1 n-9, and C24:1 n-9.

${ }^{e}$ Polyunsaturated fatty acids: C18:2 n-6, C18:2 c9, t11, C18:3 n-6, C18:3 n-3, C20:2, C20:3 n-6, C20:4 n-6, C20:5 n-3, and C22:4 n-6.

${ }^{f}$ Unsaturated fatty acids (monounsaturated and polyunsaturated fatty acids).

bulls were fed the 60:40 F:C ratio diet. As reported earlier, although L. buchneri reduced NDF content in corn silage, the iNDF content of inoculated silage on an NDF basis was greater than that of untreated silage. The iNDF comprises the part of the indigestible fiber fraction and has a slower digestion rate (Sniffen et al.1992). Therefore, the greater percentage of iNDF in fiber fraction of this treatment may have depressed fiber digestibility which was also reflected by a reduction in DM digestibility (Mertens 2011).

Although the total VFAs were unaffected by inoculation of corn silage, an interaction between $\mathrm{F}: \mathrm{C}$ ratio and inoculation was observed for ruminal fluid $\mathrm{pH}$, which was reduced mainly when bulls were fed with the 60:40 F:C_I diet. Moreover, bulls fed the 40:60 F:C diet exhibited greater production of total VFA than bulls fed the 
60:40 F:C diet. There was an interaction between $\mathrm{F}: \mathrm{C}$ ratio and inoculation for acetic and propionic acids. Acetic acid decreased and propionic acid increased when bulls were fed the 40:60 F:C_I diet, likely because the diet consumed had lesser NDF content and greater NFC content than other treatments. Bulls fed the 40:60 F:C_I diet had a greater amount of available concentrate to consume, and readily fermentable carbohydrates contribute to a greater production of propionic and butyric acids, as well as a greater production of total VFA (Hoover 1986). Consequently, the ruminal fluid of bulls fed the 40:60 F:C_I diet had the lowest acetic acid:propionic acid ratio. However, propionic acid decreased when bulls were fed the 60:40 F:C_I diet. Butyric acid was increased by inoculation of corn silage compared with untreated silage, and also when bulls were fed the 40:60 F:C diet compared with the 60:40 F:C diet.

Bulls fed 40:60 F:C_I diet had greater ADG compared with other diets, possibly as a result of a greater DMI. Improvements in growth performance have been observed as a result of the inoculation of silage (Weinberg and Muck 1996; Kung and Muck 1997), but in our study, only the association between inoculation and 40:60 F:C ratio increased ADG. The increment in growth performance of bulls fed the 40:60 F:C_I diet is in agreement with previous studies that reported a greater DMI and ADG in lambs fed corn silage inoculated with L. buchneri (Ranjit et al. 2002; Nkosi et al. 2009; Basso et al. 2014). However, inoculation of corn silage with L. buchneri did not enhance the performance of bulls fed the 60:40 F:C ratio likely because of the reduction in NDF and DM digestibility. The lack of positive results on animal performance regarding inoculation of silages with L. buchneri has been reported earlier (Salvo et al. 2013; Addah et al. 2014). Furthermore, feed efficiency was not affected by treatments because a greater DMI intake observed in bulls fed the 40:60 F:C_I diet led an increase in ADG, while the reduction in DMI observed with other treatments was associated with a reduction in ADG.

Bulls fed the 40:60 F:C_I and 60:40 F:C_U diets had greater LMA. The greater LMA found in bulls fed the 40:60 F:C_I diet likely is attributed to greater DMI found in this treatment, but we are not able to explain the high LMA value observed in bulls fed the 60:40 F:C_U diet. In our study, dressing percentage was similar among treatments, but bulls fed the 40:60 F:C_I and 60:40 F:C_U diets had a greater final BW (trends toward interaction between inoculation and $\mathrm{F}: \mathrm{C}$ ratio, $P=0.096$ ), and likely these bulls also had a greater carcass weight leading to increased LMA (Lage et al. 2012). The values of KPH were unaffected by treatments, most likely due to sorting of diets, and the bulls maintaining similar levels of feed efficiency.

The meat colors $\mathrm{a}^{*}$ and $\mathrm{b}^{*}$ of the bulls fed 40:60 F:C diets were more intense than those fed 60:40 F:C diets, but the cause of this effect is extremely difficult to evaluate because more than one factor plays an important role such as carcass fatness, meat terminal $\mathrm{pH}$, carcass weight, and intramuscular fat (Priolo et al. 2001). Moreover, the lipid oxidation in meat is related to TBA concentration, and lesser levels of TBA can be indicative of reduced lipid oxidation (Gatellier et al. 2005). In this regard, bulls fed 40:60 F:C diets probably had less lipid oxidation in the meat, most likely because the concentrate used in this study was a mixture of ground corn and soybean meal. These feedstuffs are rich in tocopherols and tocotrienols that display antioxidant properties (Chow and Draper 1974), which can reduce the formation of TBA during the cooking of meat.

We did not observe changes in the CL as a result of silage inoculation or the $\mathrm{F}: \mathrm{C}$ ratio. As a result, the WBSF was unaffected by treatment, results that are in agreement with those reported by Lage et al. $(2012,2014 a)$ as they also observed no difference in beef tenderness of bulls (40\% and $60 \%$ of concentrate in the diet) and heifers ( $30 \%$ and $50 \%$ of concentrate in the diet).

Corn silage inoculated with L. buchneri had lesser concentrations of lauric and palmitic acids, and the meat of bulls fed diets containing inoculated silage also had lesser concentrations of these acids. Likewise, inoculated silage had greater concentration of oleic acid leading to an increase of this fatty acid in the meat of bulls fed diets composed of this silage. The oleic, stearic, linoleic, palmitoleic, and vaccenic acids comprised more than 95\% of the fatty acids in the longissimus muscle in our study. Both oleic and linoleic acids can positively impact meat health attributes, reducing the concentration of low-density lipoprotein (LDL) cholesterol and raising the concentration of high-density lipoprotein (HDL) cholesterol in the blood (Fugita et al. 2012). Furthermore, inoculation increased the concentration of nervonic acid, besides oleic acid, which may explain the greater amount of MUFA, UFA, and omega-9 fatty acids, as well as the UFA:SFA ratio in the meat of bulls fed diets composed of inoculated silage. Any amount of omega-9 consumed is beneficial because these FFAs can protect against heart disease in humans, but in balancing these fatty acids, the omega-3 component is the most important (Asif 2011). Consequently, there is a potential to use silage inoculant to improve the FFA profile in the meat of beef cattle, but this must be investigated in future studies to know the mechanisms of action from L. buchneri on the FFA profile and their ideal application rate in the silage.

In the present study, bulls fed the 40:60 F:C diets had greater concentration of PUFA, omega- 6 fatty acids, and PUFA:SFA ratio compared with bulls fed the 60:40 F:C diets, and these responses likely are associated with alterations in ruminal fermentation that could affect fatty acid biohydrogenation. Increases in PUFA and PUFA:SFA ratio are positive aspects in meat quality of beef cattle that has been suggested to prevent cardiovascular diseases in humans (Wood et al. 2004). It is recommended that PUFA:SFA ratio should be increased to 
above 0.4 (Wood et al. 2004). In this regard, bulls fed the 40:60 F:C diet had greater PUFA:SFA ratio than those fed the 60:40 F:C diet (0.105 vs. 0.086, respectively). Although inoculation of corn silage did not affect the PUFA:SFA ratio, bulls fed the 60:40 F:C and 40:60 F:C diets containing inoculated and untreated silages had values above 0.4 .

\section{Conclusions}

Inoculation of corn silage with L. buchneri increased feed intake and growth performance of finishing feedlot beef cattle only when they were fed with 40:60 F:C diet. However, DM and NDF digestibility decreased when corn silage was inoculated. Inoculation of corn silage with L. buchneri also tended to increase the concentrations of UFA and MUFA in the meat of beef cattle. The concentrations of PUFA and omega- 6 fatty acids were increased when bulls were fed the 40:60 F:C diet compared with a 60:40 F:C diet.

\section{Acknowledgements}

We are grateful to the São Paulo Research Foundation (Process 2011/04547-9 and 2012/00412-4) for financial support. We also thank Douglas de Souza Castagnino and Sophie Brajon by support with the French language.

\section{References}

Abularach, M.L.S., Rocha, C.E., and Felício, P.E. 1998. Quality traits of boneless rib cut (L. dorsi muscle) from Nelore young bulls. Ciênc. Tecnol. Aliment. 18: 205-210. doi:10.1590/ S0101-20611998000200012. PMID:27368110.

Addah, W., Baah, J., Okine, E.K., Owens, F.N., and McAllister, T.A. 2014. Effects of chop-length and a ferulic acid esteraseproducing inoculant on fermentation and aerobic stability of barley silage, and growth performance of finishing feedlot steers. Anim. Feed Sci. Technol. 197: 34-46. doi:10.1016/j. anifeedsci.2014.07.012.

American Meat Science Association (AMSA). 1995. Research guidelines for cookery, sensory evaluation and tenderness measurements of fresh meat. National Livestock and Meat Board, Chicago, IL.

Ander, B.P., Dupasquier, C.M.C., Prociuk, M.A., and Pierce, G.N. 2003. Polyunsaturated fatty acids and their effects on cardiovascular disease. Exp. Clin. Cardiol. 8: 164-172. PMID:19649216.

Arriola, K.G., Kim, S.C., Staples, C.R., and Adesogan, A.T. 2011. Effect of applying bacterial inoculants containing different types of bacteria to corn silage on the performance of dairy cattle. J. Dairy Sci. 94: 3973-3979. doi:10.3168/jds.2010-4070. PMID:21787933.

Ashbell, G., and Weinberg, Z.G. 1992. Top silage losses in horizontal silos. Can. Agric. Eng. 34: 171-175.

Ashbell, G., Weinberg, Z.G., Hen, Y., and Filya, I. 2002. The effects of temperature on the aerobic stability of wheat and corn silages. J. Ind. Microbiol. Biotechnol. 28: 261-263. doi:10.1038/sj.jim.7000237. PMID:11986929.

Asif, M. 2011. Health effects of omega-3,6,9 fatty acids: Perilla frutescens is a good example of plant oils. Orient. Pharm. Exp. Med. 11: 51-59. doi:10.1007/s13596-011-0002-x. PMID:21909287.

Association of Official Analytical Chemists (AOAC). 1996. Official methods of analysis. 16th ed. AOAC, Arlington, VA.
Barker, S.B., and Summerson, W.H. 1941. The colorimetric determination of lactic acid in biological material. J. Biol. Chem. 138: 535-554.

Basso, F.C., Adesogan, A.T., Lara, E.C., Rabelo, C.H.S., Berchielli, T.T., Teixeira, I.A.M.A., Siqueira, G.R., and Reis, R.A. 2014. Effects of feeding corn silage inoculated with microbial additives on the ruminal fermentation, microbial protein yield, and growth performance of lambs. J. Anim. Sci. 92: 5640-5650. doi:10.2527/jas.2014-8258. PMID:25414110.

Bligh, E.G., and Dyer, W.J. 1959. A rapid method of total lipid extraction and purification. Can. J. Biochem. Physiol. 37: 911-917. doi:10.1139/o59-099. PMID:13671378.

Boufaïed, H., Chouinard, P.Y., Tremblay, G.F., Petit, H.V., Michaud, R., and Bélanger, G. 2003. Fatty acids in forages. I. Factors affecting concentrations. Can. J. Anim. Sci. 83: 501-511. doi:10.4141/A02-098.

Chow, C.K., and Draper, H.H. 1974. Oxidative stability and activity of the tocopherols in corn and soybean oils. Int. J. Vit. Nutr. Res. 44: 396-403.

French, P., Stanton, C., Lawless, F., O’Riordan, E.G., Monahan, F.J., Caffrey, P.J., and Moloney, A.P. 2000. Fatty acid composition, including conjugated linoleic acid, of intramuscular fat from steers offered grazed grass, grass silage, or concentrate-based diets. J. Anim. Sci. 78: 2849-2855. PMID:11063308.

Fugita, C.A., Prado, I.N., Jobim, C.C., Zawadzki, F., Valero, M.V., Pires, M.C.O., Prado, R.M., and Françozo, M.C. 2012. Corn silage with and without enzyme-bacteria inoculants on performance, carcass characteristics and meat quality in feedlot finished crossbred bulls. Brazil. J. Anim. Sci. 41: 154-163.

Gatellier, P., Mercier, Y., Juin, H., and Renerre, M. 2005. Effect of finishing mode (pasture- or mixed-diet) on lipid composition, colour stability and lipid oxidation in meat from Charolais cattle. Meat Sci. 69: 175-186. doi:10.1016/j.meatsci.2004. 06.022. PMID:22062653.

Greiner, S.P., Rouse, G.H., Wilson, D.E., Cundiff, L.V., and Wheeler, T.L. 2003. Prediction of retail product weight and percentage using ultrasound and carcass measurements in beef cattle. J. Anim. Sci. 81: 1736-1742. PMID:12854810.

Han, H., Ogata, Y., Yamamoto, Y., Nagao, S., and Nishino, N. 2014. Identification of lactic acid bacteria in the rumen and feces of dairy cows fed total mixed ration silage to assess the survival of silage bacteria in the gut. J. Dairy Sci. 97: 5754-5762. doi:10.3168/jds.2014-7968. PMID:24996273.

Hoover, W.H. 1986. Chemical factors involved in ruminal fiber digestion. J. Dairy Sci. 69: 2755-2766. doi:10.3168/jds. S0022-0302(86)80724-X. PMID:3027148.

International Organization for Standardization (ISO). 1978. Method ISO 5509. ISO, Geneva, Switzerland. 6 pp.

Jenkins, T.C. 1993. Lipid metabolism in the rumen. J. Dairy Sci. 76: 3851-3863. doi:10.3168/jds.S0022-0302(93)77727-9. PMID:8132891.

Klaenhammer, T.R. 1993. Genetics of bacteriocins produced by lactic acid bacteria. FEMS Microbiol. Rev. 12: 39-85. doi:10.1111/j.1574-6976.1993.tb00012.x. PMID:8398217.

Kleinschmit, D.H., and Kung, L., Jr. 2006. A meta-analysis of the effects of Lactobacillus buchneri on the fermentation and aerobic stability of corn and grass and small-grain silages. J. Dairy Sci. 89: 4005-4013. doi:10.3168/jds.S0022-0302(06) 72444-4. PMID:16960077.

Kung, L., Jr., and Muck, R.E. 1997. Animal response to silage additives. In Silage: field to feedbunk. Northeast Regional Agricultural Engineering Service, Ithaca, NY, NRAES-99. pp. 200-210.

Kung, L., Jr., Grieve, D.B., Thomas, J.W., and Huber, J.T. 1984. Added ammonia or microbial inoculant for fermentation and nitrogenous compounds of alfalfa ensiled at various percents of dry matter. J. Dairy Sci. 67: 299-306. doi:10.3168/jds. S0022-0302(84)81302-8. 
Lage, J.F., Berchielli, T.T., San Vito, E., Silva, R.A., Ribeiro, A.F., Reis, R.A., Dallantonia, E.E., Simonetti, L.R., Delevatti, L.M., and Machado, M. 2014a. Fatty acid profile, carcass and meat quality traits of young Nellore bulls fed crude glycerin replacing energy sources in the concentrate. Meat Sci. 96: 11581164. doi:10.1016/j.meatsci.2013.10.027.

Lage, J.F., Paulino, P.V.R., Pereira, L.G.R., Duarte, M.S., Valadares Filho, S.C., Oliveira, A.S., Souza, N.K.P., and Lima, J.C.M. $2014 b$. Carcass characteristics of feedlot lambs fed crude glycerin contaminated with high concentrations of crude fat. Meat Sci. 96: 108-113. doi:10.1016/j.meatsci.2013.06.020.

Lage, J.F., Paulino, P.V.R., Valadares Filho, S.C., Souza, E.J.O., Duarte, M.S., Benedeti, P.D.B., Souza, N.K.P., and Cox, R.B. 2012. Influence of genetic type and level of concentrate in the finishing diet on carcass and meat quality traits in beef heifers. Meat Sci. 90: 770-774. doi:10.1016/j. meatsci.2011.11.012. PMID:22127147.

Mandell, I.B., Buchanan-Smith, J.G., and Campbell, C.P. 1998. Effects of forage vs grain feeding on carcass characteristics, fatty acid composition, and beef quality in Limousin-Cross steers when time on feed is controlled. J. Anim. Sci. 76: 2619-2630. PMID:9814903.

McDonald, P., Henderson, A.R., and Heron, S.J.E. 1991. The biochemistry of silage. 2nd ed. Chalcomb Publications, Marlow, Bucks, UK.

Mertens, D.R. 1977. Dietary fiber components, relationship to the rate and extent of ruminal digestion. Fed. Proceed. 36: 187-192.

Mertens, D.R. 2011. Measurements of forage quality. Proc. Tri-State Dairy Nutrition Conference. Purdue University, Michigan State University, Ohio State University.

Mohammed, R., Stevenson, D.M., Beauchemin, K.A., Muck, R.E., and Weimer, P.J. 2012. Changes in ruminal bacterial community composition following feeding of alfalfa ensiled with a lactic acid bacterial inoculants. J. Dairy Sci. 95: 328-339. doi:10.3168/jds.2011-4492. PMID:22192212.

National Research Council (NRC). 2000. Nutrients requirements of beef cattle. 7th ed. National Academies Press, Washington, DC.

Nkosi, B.D., Meeske, R., Langa, T., and Thomas, R.S. 2011. Effects of bacterial silage inoculants on whole-crop maize silage fermentation and silage digestibility in rams. S. Afr. J. Anim. Sci. 41: 350-359. doi:10.4314/sajas.v41i4.5.

Nkosi, B.D., Meeske, R., Palic, D., Langa, T., Leeuwa, K.J., and Groenewald, I.B. 2009. Effects of ensiling whole crop maize with bacterial inoculants on the fermentation, aerobic stability, and growth performance of lambs. Anim. Feed Sci. Technol. 154: 193-203. doi:10.1016/j.anifeedsci.2009.09.009.

Nuernberg, K., Dannenberger, D., Nuernberg, G., Ender, K., Voigt, J., Scollan, N.D., Wood, J.D., Nute, G.R., and Richardson, R.I. 2005. Effect of a grass-based and a concentrate feeding system on meat quality characteristics and fatty acid composition of longissimus muscle in different cattle breeds. Liv. Prod. Sci. 94: 137-147. doi:10.1016/j. livprodsci.2004.11.036.

Oliveira, D.M., Ladeira, M.M., Chizzotti, M.L., Machado Neto, O.R., Ramos, E.M., Goncalves, T.M., Bassi, M.S., Lanna, D.P.D., and Ribeiro, J.S. 2011. Fatty acid profile and qualitative characteristics of meat from zebu steers fed with different oilseeds. J. Anim. Sci. 89: 2546-2555. doi:10.2527/jas.2010-3553. PMID:21383038.

Oude Elferink, S.J.W.H., Krooneman, J., Gottschal, J.C., Spoelstra, S.F., Faber, F., and Driehuis, F. 2001. Anaerobic conversion of lactic acid to acetic acid and 1,2-propanediol by Lactobacillus buchneri. Appl. Environ. Microbiol. 67: 125-132. doi:10.1128/AEM.67.1.125-132.2001. PMID:11133436.
Pina, D.S., Valadares Filho, S.C., Detmann, E., Valadares, R.F.D., Campos, J.M.S., Moraes, K.A.K., Oliveira, A.S., and Paixão, M.L. 2006. Comparison of internal markers and extent of total fecal collection to estimate nutrient digestibility and energy value of feeds on dairy cows fed different protein sources. Brazil. J. Anim. Sci. 35: 2461-2468.

Priolo, A., Micol, D., and Agabriel, J. 2001. Effects of grass feeding systems on ruminant meat colour and flavour. A review. Anim. Res. 50: 185-200. doi:10.1051/animres:2001125.

Ranjit, N.K., Taylor, C.C., and Kung, L., Jr. 2002. Effect of Lactobacillus buchneri 40788 on the fermentation, aerobic stability and nutritive value of maize silage. Grass For. Sci. 57: 73-81. doi:10.1046/j.1365-2494.2002.00304.x.

Ryan, S.M., Unruh, J.A., Corrigan, M.E., Drouillard, J.S., and Seyfert, M. 2007. Effects of concentrate level on carcass traits of Boer crossbred goats. Small Rumin. Res. 73: 67-76. doi:10.1016/j.smallrumres.2006.11.004.

Salvo, P.A.R., Basso, F.C., Rabelo, C.H.S., Oliveira, A.A., Sader, A.P., Casagrande, D.R., Berchielli, T.T., and Reis, R.A. 2013. Characteristics of corn silages inoculated with Lactobacillus buchneri and L. plantarum. Arch. Zootec. 62: 379-390 [in Portuguese, English abstract].

Scollan, N., Hocquette, J.-F., Nuernberg, K., Dannenberger, D., Richardson, I., and Moloney, A. 2006. Innovations in beef production systems that enhance the nutritional and health value of beef lipids and their relationship with meat quality. Meat Sci. 74: 17-33. doi:10.1016/j.meatsci.2006.05.002. PMID:22062713.

Sniffen, C.J., O’Connor, J.D., Van Soest, P.J., Fox, D.G., and Russell, J.B. 1992. A net carbohydrate and protein system for evaluating cattle diets: II. Carbohydrate and protein availability. J. Anim. Sci. 70: 3562-3577. PMID:1459919.

Valente, T.N.P., Detmann, E., Valadares Filho, S.C., Cunha, M., Queiroz, A.C., and Sampaio, C.B. 2011. In situ estimation of indigestible compounds contents in cattle feed and feces using bags made from different textiles. Brazil. J. Anim. Sci. 40: 666-675.

Van Soest, P.J., and Robertson, J.B. 1985. Analysis of forages and fibrous foods. Cornell University, Ithaca, NY.

Van Soest, P.J., Robertson, J.B., and Lewis, B.A. 1991. Methods for dietary fiber, neutral detergent fiber, and non starch polysaccharides in relation to animal nutrition. J. Dairy Sci. 74: 3583-3597. doi:10.3168/jds.S0022-0302(91)78551-2. PMID:1660498.

Warren, H.E., Scollan, N.D., Enser, M., Hughes, S.I., Richardson, R.I., and Wood, J.D. 2008. Effects of breed and a concentrate or grass silage diet on beef quality in cattle of 3 ages. I: animal performance, carcass quality and muscle fatty acid composition. Meat Sci. 78: 256-269. doi:10.1016/j.meatsci.2007.06.008. PMID:22062278.

Weinberg, Z.G., and Muck, R.E. 1996. New trends and opportunities in the development and use of inoculants for silage. FEMS Microbiol. Rev. 19: 53-68. doi:10.1111/j.1574-6976.1996. tb00253.x.

Weinberg, Z.G., Muck, R.E., and Weimer, P.J. 2003. The survival of silage inoculant lactic acid bacteria in rumen fluid. J. Appl. Microbiol. 94: 1066-1071. doi:10.1046/j.1365-2672.2003. 01942.x. PMID:12752816.

Wood, J.D., Richardson, R.I., Nute, G.R., Fisher, A.V., Campo, M.M., Kasapidou, E., Sheard, P.R., and Enser, M. 2004. Effects of fatty acids on meat quality: a review. Meat Sci. 66: 21-32. doi:10. 1016/S0309-1740(03)00022-6. PMID:22063928.

Yildirim, M. 2001. Purification of buchnericin LB produced by Lactobacillus buchneri LB. Turk. J. Biol. 25: 59-65. 